\title{
Wpływ działalności antropogenicznej na obecną strukturę genetyczną populacji drzew leśnych
}

\author{
Justyna Anna Nowakowska \\ Instytut Nauk Biologicznych, Wydział Biologii i Nauk o Środowisku \\ Uniwersytet Kardynała Stefana Wyszyńskiego w Warszawie, ul. Wóycickiego 1/3, 01-938 Warszawa \\ j.nowakowska@uksw.edu.pl
}

\begin{abstract}
Streszczenie
Działalność człowieka od zawsze miała wpływ na skład gatunkowy i strukturę genetyczną gatunków tworzących ekosystem leśny. Wyniki badań DNA potwierdzają wpływ obecnej i przeszłej gospodarki leśnej na obecny poziom zmienności genetycznej populacji drzew leśnych. Analiza molekularna pozwala określić pokrewieństwo genetyczne gatunków drzew leśnych, umożliwia badanie przepływu genów między pokoleniami, oraz odzwierciedla historię polodowcowej migracji gatunków z refugiów południowej Europy do Polski. Dzięki markerom DNA można precyzyjnie odróżnić mieszańce gatunkowe np. modrzewia japońskiego i europejskiego. Porównanie profili DNA kradzionego drzewa z pniakiem pozostawionym w lesie, dostarcza mocnych dowodów w sprawach dotyczących nielegalnego handlu drewnem. Genetyczna transformacja genomu drzew pozwala uzyskać drewno o zmienionej strukturze lignin, oraz zwiększoną asymilację $\mathrm{CO}_{2}$ w liściach. Modyfikacje genetyczne zmierzają też w kierunku wzmocnionej odporności hodowanych gatunków drzew na patogeny grzybowe lub szkodniki owadzie oraz na środki ochrony roślin na plantacjach drzew szybkorosnących GMO.
\end{abstract}

\section{Słowa kluczowe}

drzewa leśne, markery DNA, inżynieria genetyczna, gospodarka leśna

\section{Wstęp}

Człowiek od zarania dziejów modyfikował i wpływał na stan przyrody, korzystając z jej zasobów wedle swoich potrzeb. Dzięki ostatnim odkryciom biologii molekularnej, powstały nowe narzędzia umożliwiające rozwiązanie kluczowych problemów, dotyczących optymalnego zarządzania różnorodnością genetyczną na poziomie wewnątrz-i między-populacyjnym w drzewostanach naturalnych i gospodarczych, oraz na plantacjach i w szkółkach leśnych.
Geny, czyli kodujące sekwencje cząsteczek kwasu deoksyrybonukleinowego (DNA), są nośnikiem informacji genetycznej nt. struktury, aktywności enzymatycznej i regulacji procesów życiowych rośliny. Pozostałe sekwencje, niekodujące, biorą udział w procesach regulacji ekspresji DNA i są cennym źródłem informacji o zmienności genetycznej pojedynczych organizmów oraz całych populacji. W pracy, omówiono główne przykłady zastosowania osiągnięć współczesnej 
biologii molekularnej i biotechnologii we współczesnym leśnictwie.

\section{Ochrona bioróżnorodności lasu}

Różnorodność genetyczna gatunków zasiedlających dany ekosystem jest kluczowym elementem równowagi i ciągłości trwania ekosystemu w czasie. Nie tylko poznanie liczby gatunków zasiedlających daną niszę ekologiczną ma znaczenie, ale również zmienność wewnątrzgatunkowa, w obrębie jednej populacji lub pomiędzy wieloma populacjami danego gatunku. Lasy tworzą największe ekosystemy na Ziemi, a ich różnorodność gatunkowa i osobnicza gwarantuje równowagę całej planety. Analizy cząsteczek DNA umożliwiają bezpośrednie poznanie różnorodności genetycznej organizmów dzięki uniwersalności kodu genetycznego, oraz dziedziczeniu jednostek informacji genetycznej (genów) wg praw Mendla. Genomika drzew leśnych bada przepływ informacji genetycznej na poziomie ekspresji genów, czyli przeniesienia informacji zapisanej w sekwencji genu do sekwencji białka. Najczęściej badanym gatunkiem jest topola, ponieważ ma dość mały genom (ok. $500 \mathrm{Mb}$ ), w porównaniu do sosny (2200o Mb), zaś tylko 4 razy większy od rośliny modelowej Arabidopsis thaliana L. (Bennett et al. 2003: 547-557, Bradshaw et al. 2000: 306-313, Zimin et al. 2014: 875-89o). Markery molekularne DNA są powszechnie stosowane $\mathrm{w}$ analizach powiązań filogenetycznych gatunków spokrewnionych, np. w obrębie rodzaju Pinus: u sosny zwyczajnej (P. sylvestris L.), sosny hakowatej (P. uncinata), kosodrzewiny (P. mugo Turra) i sosny błotnej (P. uliginosa) (Wachowiak, Prus Głowacki 2008: 29-40, Celiński et al. 2013: 621-626, Polok et al. 2016: 573-581), oraz $\mathrm{w}$ przypadku odróżnienia $\mathrm{w}$ drzewostanie mieszańców modrzewia europejskiego ( $L a$ rix decidua Mill.) od modrzewia japońskiego (Larix kaempferi Sorg.) (Jagielska 2008: 21$25)$. Badania wpływu antropopresji na populacje drzew leśnych szczegółowo badano dla populacji sosen z terenów skażonych radioaktywnym cezem w Czernobylu (Vornam et al. 2004: 245-248) oraz populacji poddanych oddziaływaniu metali ciężkich w glebie (Chudzinska et al. 2014: 533-539).

Analiza sekwencji DNA organellowego jest jednym z doskonałych narzędzi, które umożliwia odtworzenie historycznych dróg migracji polodowcowej z głównych refugiów lodowcowych z południa i północy Europy dla wielu gatunków drzew leśnych, tj. dęby, sosna i świerk. Analiza niekodujących regionów trnD-trn T chloroplastowego DNA u dębów (Quercus robur L., Q. petraea Liebl.) potwierdziła występowanie czterech głównych dróg migracji w Europie, oraz przynależność większości polskich populacji dębów do dębów z Półwyspu Bałkańskiego (Petit et al. 2002: 49-74). Polimorfizm mitochondrialnych genów NADH dehydrogenazy u świerka (Picea abies L. Karst.) i sosny (Pinus sylvestris L.) w Europie wskazuje na zasiedlanie kontynentu przez te gatunki głównie z refugiów z południa Europy oraz, w drugiej fali migracji polodowcowej, z rejonów nordycko-bałtyckich i środkowej Rosji (Sperisen et al. 1998: 13-417, Naydenov et al. 2007: 233).

Badanie struktury genetycznej drewna przeprowadzone na podstawie analizy DNA jest metodą powszechnie stosowaną w kryminalistyce i botanice sądowej, ponieważ dostarcza dowodów rozstrzygających wątpliwości co do identyfikacji i pochodzenia próbki, pobranej w ilości śladowej. Do celów porównawczych materiału sądowego odczytuje się informacje uzyskane dzięki specyficznym gatunkowo markerom DNA jądrowego i organellowego, które to umożliwiają identyfikację badanych prób drewna z blisko $100 \%$ prawdopodobieństwem. Obecnie, porównanie profili genetycznych stosowane na potrzeby botaniki sądowej jest możliwe dla wielu gatunków drzew leśnych, w tym: sosny zwyczajnej (P. sylvestris L.), świerka pospolitego (P. abies (L.) Karst.), modrzewia japońskiego (L. kaempferi Sorg.) i europejskiego (L. decidua Mill.), dębu szypułkowego (Q. robur L.) i bezszypułkowego (Q. petraea (Matt.) Liebl.), buka zwyczajnego (Fagus sylvatica L.), graba pospolitego 
(Carpinus betulus L.), brzozy brodawkowatej (Betula pendula Roth.), olszy czarnej ( $\mathrm{Al}$ nus glutinosa Gaertn.) i jesionu wyniosłego (Fraxinus excelsior L.) (Craft et al. 2007: 6470, Nowakowska, Pasternak 2014, Tereba et al. 2017: 1377-1387). Analizy DNA uzupełniają działania monitorujące nielegalny handel drewnem na poziomie Unii Europejskiej, które mają za zadanie kontrolę napływu nielegalnego surowca drzewnego oraz promocję importu drewna z legalnych źródeł (Web-1).

Poza kradzieżą drewna, sprawy sądowe mogą niekiedy dotyczyć molekularnej detekcji szkodliwych mikroorganizmów patogenów tj. Heterobasidion sp., Phytophthora sp. i Pythium sp., rozkładających drewno drzew lub powodujących zamieranie młodych sadzonek drzew w szkółkach leśnych (Nowakowska et al. 2013: 465-48o, Orlikowski et al. 2011: 322-329).

\section{Zrównoważona gospodarka zasobami leśnymi (odnowienia i zalesienia)}

Od wielu lat leśnicy wpływają na różnorodność genetyczną generacji potomnych m.in. przez prowadzenie zalesień materiałem odnowieniowym, który może pochodzić z trzech głównych źródeł: 1) z odnowienia naturalnego $\mathrm{w}$ drzewostanie, 2) z sadzonek wyhodowanych w szkółce leśnej z nasion znanego drzewostanu, bądź 3) z sadzonek pochodzących z innych źródeł pochodzenia. Wpływ tego typu działań na przyszłą pulę genową drzewostanu może być oszacowany przy pomocy markerów molekularnych DNA.

W populacjach drzew leśnych, ograniczony przepływ pyłku z drzewostanów sąsiednich powoduje niewielką różnicę pul genowych obserwowanych między rodzicami a potomstwem, zaś nieograniczony przepływ pyłku przyczynia się do powstania większych różnic w poziomie zmienności DNA między pokoleniami drzew (Wójkiewicz et al. 2016: 8). Porównanie bogactwa alleli, oraz poziomu heterozygotyczności obserwowanej i oczekiwanej u drzew dorosłych i drzew z odnowienia sosny zwyczajnej w Szwecji, nie wykazało istotnych różnic między drzewostanami naturalnymi i gospodarczymi, za wyjątkiem większej liczby alleli rzadkich w drzewostanach gospodarczych (Ryc. 1.)

Prowadzone w Polsce badania Chomicz et al. (2015: 270-278) dotyczące porównania poziomu puli genowej między odnowieniem naturalnym a pokoleniem rodzicielskim świerka pospolitego w Beskidach, wykazały pozytywny wpływ gospodarki ludzkiej na wyższy poziom zmienności genetycznej pokolenia potomnego świerka

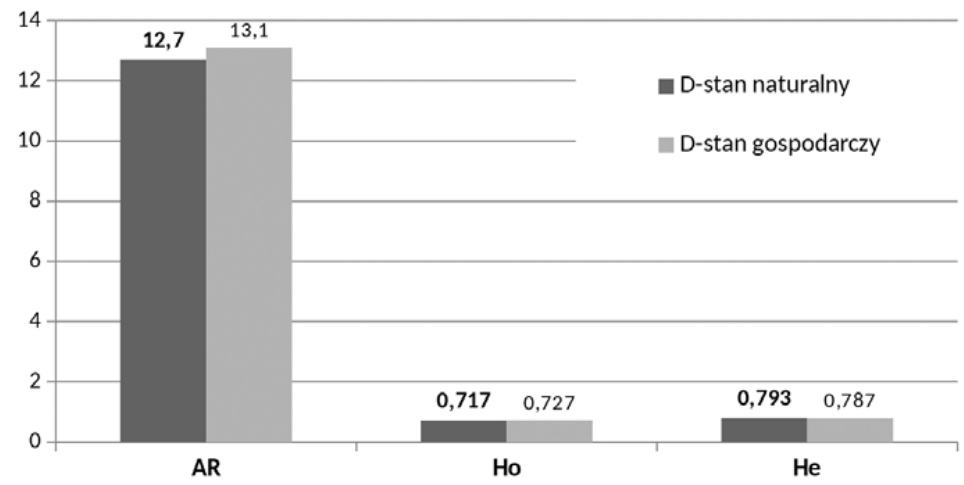

Ryc. 1. Porównanie puli genowej w drzewostanach naturalnych i gospodarczych $P$. sylvestris na podstawie bogactwa alleli (AR), oraz poziomu heterozygotyczności oczekiwanej (Ho) i obserwowanej (He) mikrosatelitarnego DNA. Dane za: García-Gil et al. (2015: 28) 
w drzewostanach gospodarczych, w porównaniu do drzewostanu objętego ochroną ścisłą w jednym rezerwacie. Wyniki te potwierdziły skuteczność działania leśników, którzy przez starannie prowadzone odnowienia zapobiegają utracie cennych genotypów świerka w zamierających, starych drzewostanach świerkowych w Beskidzie Śląskim i Żywieckim.

Analizy dwóch populacji sosny zwyczajnej odnawianej sztucznie, wykazały wpływ stosowanej metody produkcji szkółkarskiej na poziom zmienności genetycznej hodowanych sadzonek, mianowicie sadzonki hodowane metodą kontenerową miały bardziej zróżnicowaną i bogatszą pulę genową, w porównaniu do sadzonek produkowanych z odkrytym systemem korzeniowym (Konecka et al. 2018: 32-40). Najprawdopodobniej stan ten wynika z lepszych warunków wzrostu, jakie mają jednoroczne sadzonki sosny w mikoryzowanym podłożu kontenerów, w porównaniu do sadzonek rosnących w gruncie, zaś selekcja naturalna której będą poddane oba typy sadzonek $\mathrm{w}$ fazie wzrostu w drzewostanie, spowoduje dobór najbardziej przystosowanych genotypów do danych warunków siedliska.

\section{Inżynieria genetyczna drzew na plantacjach}

Hodowla selekcyjna drzew leśnych od lat zmierza w kierunku selekcji korzystnych cech ilościowych DNA (ang. Quantitative Trait Loci - QTL) kodujących takie cechy, jak: wielkość biomasy, gęstość drewna, odpowiedź na stres biotyczny i abiotyczny (Strauss et al. 2001: 4-7). Selekcja odpowiednich linii drzew na podstawie wybranych genotypów zapewnia różnorodność puli genowej przyszłych drzewostanów, np. u sosny zwyczajnej z wyselekcjonowanym genem wzrostu (Nowicka et al. 2013: 168-173). Dalej, dzięki odpowiedniemu doborowi nasion pochodzących z drzew o znanym genotypie, możliwe jest planowanie odnowień i zalesień w razie klęsk takich, jak huragan czy pożar.

Lasy wiążą nadmiar dwutlenku węgla w atmosferze oraz ok. 7-12\% pyłów emitowanych przez przemysł w Europie. Obecna biotechnologia drzew leśnych łączy interdyscyplinarne nauki badań, od poznania regulacji procesów ekspresji genów, poprzez produkcję wyselekcjonowanych odmian drogą somatycznej embriogenezy, aż po selekcję opartą na markerach DNA (ang. marker assissted selection) odmian o cennych cechach odpornościowych i przemysłowych. I tak, dzięki poznaniu działania procesów regulacyjnych ekspresji genów odpowiadających za jakość drewna, możliwy jest wybór odpowiednich gatunków i odmian topoli w celach produkcji drewna na plantacjach. Plantacje drzew leśnych obejmują na świecie około 40 milionów hektarów $(1,2 \%$ powierzchni leśnej) i dostarczają około $25 \%$ biomasy dla przemysłu celulozowo-papierniczego, a tym samym przyczyniają się do ochrony naturalnych drzewostanów wobec rosnących potrzeb przemysłowej produkcji surowca drzewnego (Web-2).

Biorąc pod uwagę produkcyjną wartość surowca drzewnego i długowieczność gatunków drzew, produkty leśne można traktować jako towar wytwarzany w ramach modelu gospodarstwa rolnego, choć istnieje duża różnica między uprawami drzew, a uprawami roślin w rolnictwie - zwłaszcza w kontekście zastosowania rozwiązań nowoczesnej inżynierii genetycznej. Zmiany genetyczne stosowane w rolnictwie, choć dla ograniczonej liczby cech i gatunków, mogą stanowić wyzwanie dla naukowców i praktyków związanych z sektorem leśnym, w kontekście możliwości zastosowania drzew zmodyfikowanych genetycznie w produkcji surowca drzewnego. Temat ten wzbudza żywe dyskusje w społeczeństwie, ponieważ wciąż istnieje obawa przed nowymi technikami inżynierii genetycznej, stosowanej do produkcji roślin GMO (ang. Genetically Modified Organisms). Na świecie, w najbliższej przyszłości nie wyklucza się również hodowli na szeroką skalę genetycznie zmodyfikowanych drzew (ang. GMT - Genetically Modified Trees), do których wprowadzane są różne geny (Kellison 2007: 279-288). Uprawy i obrót GMO 
w Polsce są możliwe od 28.01.2013 r., dzięki ustawie o nasiennictwie oraz ustawie $\mathrm{z}$ dnia 22 czerwca 2001 r. o organizmach genetycznie zmodyfikowanych (Dz. U. z 2001 r. Nr 76, poz. 811 oraz z 2002 r. Nr 25, poz. 253).

Modyfikacja genomu roślin opiera się na genetycznej transformacji ich komórek, przez wprowadzenie specyficznej sekwencji obcego DNA. Dzieje się to na drodze tzw. transformacji wektorowej za pomocą bakterii Agrobacterium tumefaciens (Ryc. 2), lub bezwektorowej, przy użyciu strzelby genowej (Sanford 1990: 206-209).

Na ogół produkcja gatunków transgenicznych jest ukierunkowana na wprowadzenie do komórek rośliny genu, którego produkt (białko) nadaje jej znane korzyści hodowlane, jak np. wzmocnienie odporności na patogeny grzybowe i szkodniki owadzie, oraz na środki ochrony roślin (herbicydy i pestycydy) w celu tworzenia plantacji szybkorosnących GMO, przy zachowaniu niskich kosztów uprawy (Ryc. 3).

Spośród gatunków drzew najwięcej modyfikacji genetycznych wykonuje się na topoli Populus spp., do któej wprowadzane są nowe geny odporności na czynniki biotyczne, np. gen Bt z Bacillus thuringiensis, nadający odporność na owady z rzędu błonkówek, muchówek i motyli, oraz czynniki abiotyczne, np. gen aro biorący udział w odporności rośliny na glifosat, wchodzący w skład herbicydu Round-up (Strauss et al. 2001: 4-7). Inne modyfikacje, stosowane u topoli i eukaliptusa, zmierzają w kierunku wzrostu sekwestracji dwutlenku węgla w ekosystemach leśnych przez zwiększenie efektywności fotosyntezy, głównie przez mutagenezę sterowaną genu Rubisco w kierunku zwiększonej aktywności karboksylowej, kosztem aktywności oksydacyjnej (Campbell 2003: 141-154). U większości roślin z półkuli północnej, enzym rybulozo-1,5-bisfosforanu karboksylaza-oksygenaza (Rubisco) wiąże cząsteczki $\mathrm{CO}_{2}$ z atmosfery w tzw. cyklu $\mathrm{C}_{3}$ fotosyntezy, zaś uwalnia tlen przez fotooddychanie. Ponadto, badania na innych roślinach udowodniły, że wprowadzając gen AtTPS1 z rzodkiewnika pospolitego (A. thaliana L.) do tytoniu, można uzyskać lepszą przyswajalność wody z podłoża i wzrost aktywności fotosyntetycznej Rubisco (Almeida et al. 2007: 113-126).

W ostatnich dziesięcioleciach, wiele uwagi poświęcono badaniu genów biorących udział w molekularnych mechanizmach, warunkujących powstawanie drewna w roślinie, głównie genów białek ze szlaków

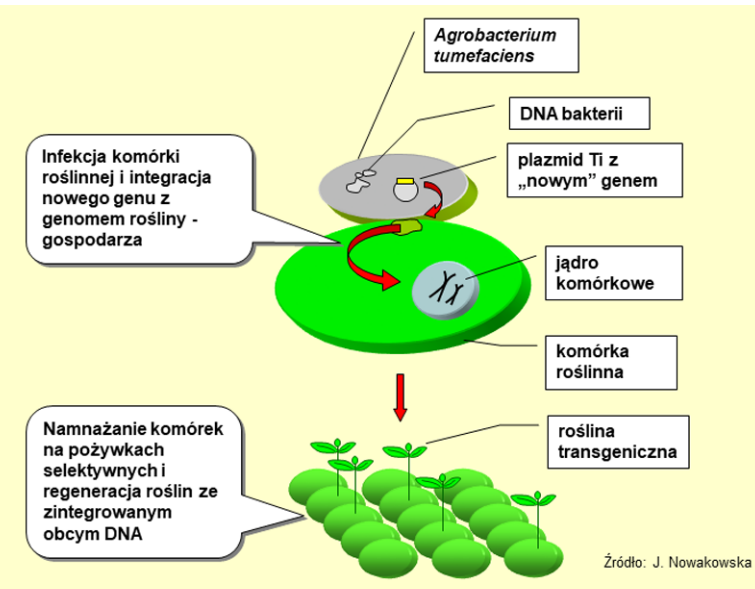

Ryc. 2. Schemat transformacji genetycznej roślin metodą wektorową, za pomocą infekcji 
Liczba uprawianych na świecie gatunków roślin GMO (stan z 2015 r.)

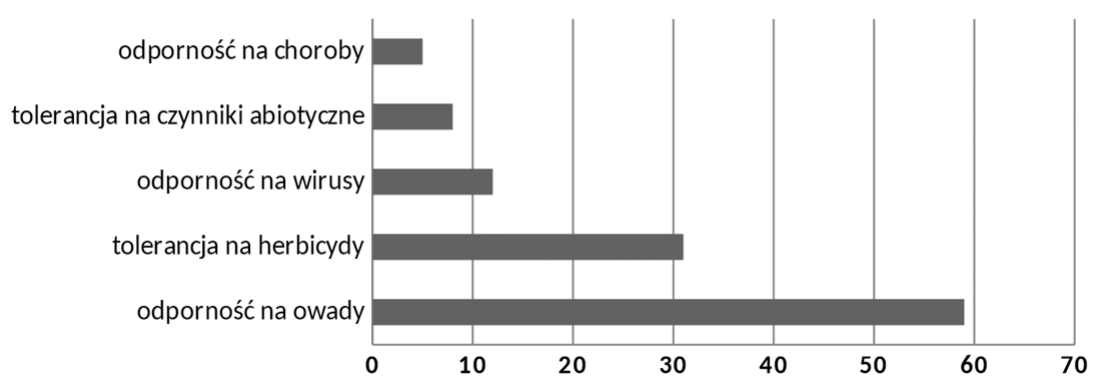

Ryc. 3. Aktualny stan uprawianych roślin transgenicznych (na podstawie Stein, Rodríguez-Cerezo 2010: 173-182)

syntezy związków polifenolowych (w tym lignin, celulozy i terpenów) oraz syntezy etylenu i fitohormonów (m.in. auksyn), białek stresu osmotycznego i metabolizmu węglowodanów (Jouanin et al. 2000: 1363-1374, Kellison et al. 2007: 448-459). Poznanie genetycznego podłoża procesu powstawania drewna umożliwia m.in. selekcję i hodowlę topól o zmodyfikowanej strukturze włókien drewna w celu łatwiejszej ich przeróbki na pulpę papierniczą. Badania w tym zakresie dotyczą głównie różnych odmian topól (P. trichocarpa, P. tremuloides, P. tremula $\mathrm{x}$ alba) z nowymi cechami właściwości drewna (dzięki zmodyfikowanej ekspresji genów C4L, CAD, PAL, COMT) i zwiększonego wzrostu drzew (modyfikacja genów $\left.G S_{1}, c e l 1, a c b\right)$ i kontrolowanemu kwitnieniu (zmodyfikowane geny Leafy i Apetala) (Nowakowska 2004: 78-86). Również inne gatunki drzewiaste, tj. eukaliptus (Eucalyptus grandis i E. globulus), sosna (Pinus taeda, P. pinaster) i orzech (Juglans nigra) są poddawane modyfikacji genetycznej ww. genów.

Warto zauważyć, że modyfikując jeden gen, możemy uzyskać kilka korzystnych cech hodowlanych na raz. Przykładem jest zablokowanie w ekspresji genów ligazy kumarynowej $C_{4} L$, kodującej kluczowy enzym w biosyntezie lignin, które prowadzi do zwiększenia biomasy i zmniejszenia o $30 \%$ zawartości lignin w drewnie topoli transgenicznej (Hu et al. 1999: 8o8-812). Obróbka chemiczna tak zmodyfikowanego surowca drzewnego skutkuje zastosowaniem mniejszej ilości szkodliwych związków chloru w przemyśle papierniczym.

Nadal poszukuje się genów odpowiedzialnych za tworzenie drewna wtórnego i genów kontrolujących proces aktywności kambium u drzew, podobnie jak działanie procesów epigenetycznych na kształtowanie cech adaptacji drzew do zmiennych warunków środowiska (Bräutigam et al. 2013: 399415). Biotechnologia drzew GMO powinna być jednak stosowana $\mathrm{z}$ rozwagą, $\mathrm{z}$ powodu ryzyka niekontrolowanego przeniesienia transgenu wraz z pyłkiem do środowiska i potencjalnej możliwości krzyżowania się transgenicznych drzew z drzewami „dzikimi” lub z pokrewnymi gatunkami w przypadku topól. Na przykład, rok roczne uwalnianie w trakcie pylenia drzewa transgenów krystalicznego białka Bt do środowiska, może skutkować uodpornieniem się szkodników na działanie toksyny.

\section{Podsumowanie}

Zastosowanie nowoczesnych technik molekularnych w nowoczesnym leśnictwie ma cenną wartość naukową, społeczną i ekonomiczną. Badania genetyczne na poziomie DNA potwierdzają wpływ działalności człowieka na współczesny stan drzewostanów 
wielu gatunków drzew leśnych, dzięki określeniu poziomu zmienności w celu ochrony zasobów genowych, poznaniu historii migracji polodowcowej, ocenie wpływu prowadzonej gospodarki leśnej na zmianę struktury drzewostanów, oraz planowaniu nowoczesnych metod hodowli lasu z uwzględnieniem inżynierii genetycznej. Warto nadmienić, że te ostatnie działania, zmierzające do powstania plantacji drzew GMO o nowych, korzystnych cechach hodowlanych, powinny być prowadzone przy zachowaniu szczególnej ostrożności, aby zapobiegać niekontrolowanym skutkom upraw GMO w środowisku.

\section{Bibliografia}

Almeida A.M., Silva A.B., Arau S.S., Cardoso L.A., Santos D.M., Torne J.M. Silva J.M., M.J. Paul, Fevereiro P.S., 2007, Responses to water withdrawal of tobacco plants genetically engineered with the AtTPS1 gene: a special reference to photosynthetic parameters, Euphytica, vol. 154, 113-126.

Bennett M.D., Leitch I.J., Price H.J., Johnston J.S., 2003, Comparisons with Caenorhabditis ( 10o Mb) and Drosophila ( 175 Mb) using flow cytometry show genome size in Arabidopsis to be $157 \mathrm{Mb}$ and thus $\sim 25 \%$ larger than the Arabidopsis genome initiative estimate of $\sim 125 \mathrm{Mb}$, Annals of Botany, vol. 91(5), 547-557.

Bradshaw, H.D., Ceulemans, R., Davis, J., Stettler, R., 200o, Emerging model systems in plant biology: poplar (Populus) as a model forest tree, Journal of Plant Growth Regulation, vol. 19(3), 306-313.

Bräutigam K., Vining K.J., Lafon-Placette C., Fossdal C.G., Mirouze M., Marcos J.G., Fluch S., Fraga M.F., Guevara M.Á., Abarca D., Johnsen Ø., Maury S., Strauss S.H., Campbell M.M., Rohde A., DíazSala C., Cervera M.T., 2013, Epigenetic regulation of adaptive responses of forest tree species to the environment. Ecology and evolution, vol. 3(2), 399-415.

Campbell M.M., Brunner A.M., Jones H.M., Strauss S.H., 2003, Forestry's fertile crescent: the application of biotechnology to forest trees, Plant Biotechnology Journal, vol. 1, 141-154.

Celiński K., Pawlaczyk E., Wojnicka-Półtorak A., Chudzińska E., Prus-Głowacki W., 2013, Cross-species amplification and characterization of microsatellite loci in Pinus mugo Turra, Biologia, vol. 68(4), 621-626.

Chomicz E., Nowakowska J.A., Tereba A., 2015, Forest decline has not reduced genetic diversity of naturally regenerated Norway spruce from the Beskids, Poland, Silvae Genetica, vol. 64(5/6), 270-278.

Chudzinska E., Pawlaczyk E.M., Celinski K., Diatta J., 2014, Response of Scots pine (Pinus sylvestris L.) to stress induced by different types of pollutantstesting the fluctuating asymmetry, Water and environment journal, vol. 28(4), 533-539.

Craft K.J., Owens J.D., Ashley A.V., 2007, Application of plant DNA markers in forensic botany: Genetic comparison of Quercus evidence leaves to crime scene trees using microsatellites, Forensic Science International, vol. 165, 64-70.

García-Gil M.R., Floran V., Östlund L., Gull B.A., 2015, Genetic diversity and inbreeding in natural and managed populations of Scots pine, Tree Genetics \& Genomes, vol. 11(2), 28.

Hu W.J., Harding S.A., Lung J., Popko J.L., Ralph J., Stokke D.D., Tsai C.J., Chiang V.L., 1999, Repression of lignin biosynthesis promotes cellulose accumulation and growth in transgenic trees, Nature Biotechnology, vol. 17, 808-812.

Jagielska A., 2008, Zastosowanie markerów genetycznych $w$ identyfikacji gatunkowej modrzewia europejskiego (Larix decidua Mill.) i japońskiego (Larix kaempferi Sorg.) oraz ich mieszańców, Leśne Prace Badawcze, vol. 69(1), 21-25.

Jouanin L., Goujon T., de Nadai V., Martin M.-T., Mila I., Vallet C. Pollet B., Yoshinaga A., Chabbert B., Petit-Conil M., Lapierre C., 200o, Lignification in transgenic poplars with extremely reduced caffeic acid O-methyltransferase activity, Plant Physiology, vol. 123, 1363-1374.

Kellison R., 2007, Value-added products from forest biotechnology, Euphytica, vol. 154, 279-288.

Kellison R.C., Balocchi C.E., Valenzuela S., Rodriguez J., 2007, Forest biotechnology: an extension of tree improvement, International Journal of Biotechnology, vol. 9, 448-459.

Konecka A., Tereba A., Bieniek J., Nowakowska J.A., 2018, Porównanie zmienności genetycznej pokolenia matecznego i sztucznie wyhodowanego potomstwa sosny zwyczajnej na podstawie analiz $D N A$, Sylwan, vol. 162(1), 32-40.

Naydenov K., Senneville S., Beaulieu J., Tremblay F., Bousquet J., 2007, Glacial variance in Eurasia: 
mitochondrial DNA evidence from Scots pine for a complex heritage involving genetically distinct refugia at mid-northern latitudes and in Asia Minor, BMC Evolutionary Biology, vol. 7(1), 233.

Nowakowska J., 2004, Zastosowanie roślin transgenicznych w leśnictwie - perspektywy i zagrożenia, Biotechnologia, vol. 3(66), 78-86.

Nowakowska J.A., Borys M., Oszako T., 2013, Detection of Heterobasidion annosum (s. str.) and H. parviporum in infected Picea abies (L. Karst.) stumps based on DNA analysis, Problems of Forensic Sciences, vol. 93, 465-48o.

Nowakowska J.A., Pasternak T., 2014, Zastosowanie analiz DNA drewna w postępowaniu karnym, wyd. CILP, Warszawa.

Nowicka A., Ukalska J., Simińska J., Szyp-Borowska I., 2013, Characterization and mapping of QTL used in breeding of Scots pine (Pinus sylvestris L.), Folia Forestalia Polonica Seria A-Forestry, vol. 55(4), 168-173.

Orlikowski L.B., Oszako T., Ptaszek M., 2011, Zagrożenie szkótek leśnych przez gatunki Phytophthora, Sylwan, vol. 155(5), 322-329.

Petit R.J., Brewer S., Bordács S., Burg K., Cheddadi R., Coart E., Cottrell J., Csaikl U.M., van Dam B., Deans J. D., Espinel S., Fineschi S., Finkeldey R., Glaz I., Goicoechea P.G., Jensen J.S., König A.O., Lowe A. J., Madsen S.F., Mátyás G., Munro R.C., Popescu F., Slade D., Tabbener H., Taurchini D., de Vries S.G.M., Ziegenhagen B., Beaulieu J.L., Kremer A., 2002, Identification of refugia and post-glacial colonization routes of European white oaks based on chloroplast DNA and fossil pollen evidence, Forest Ecology Management, vol. 156, 49-74.

Polok K., Zwijacz-Kozica T., Zieliński R., 2016, Weryfikacja pochodzenia drzewiastych form kosodrzewiny na terenie Tatrzańskiego Parku Narodowego na podstawie polimorfizmu miejsc insercji transpozonów, Sylwan, vol. 16o(7), 573-581.

Sperisen C., Büchler U., Mátyás G., 1998, Genetic variation of mitochondrial DNA reveals subdivision of Norway spruce (Picea abies (L.) Karst.), in: Karp A., Isaac P.G., Ingram D.S. (eds.) "Molecular tools for screening biodiversity”, Springer, Dordrecht, 413-417.

Sanford J.C., 1990, Biolistic plant transformation, Physiologia Plantarum, vol. 79(1), 206-209.
Stein A.J., Rodríguez-Cerezo E., 2010, Low-level presence of new GM crops: an issue on the rise for countries where they lack approval, AgBioForum, vol. 13(2), 173-182.

Strauss S.H., Campbell M.M., Pryor S.N., Coventry P., Burley J., 2001, Plantation certification and genetic engineering: FSCs ban on research is counterproductive, Journal of Forestry, vol. 99(12), 4-7.

Tereba A., Woodward S., Konecka A., Bieniek J., Nowakowska J.A., 2017, Analysis of the DNA profile of ash (Fraxinus excelsior L.) to provide evidence of illegal logging, Wood Science and Technology, vol. 51(6), 1377-1387.

Wachowiak W., Prus-Głowacki W., 2008, Hybridisation processes in sympatric populations of pines Pinus sylvestris L., P. mugo Turra and P. uliginosa Neumann, Plant Systematics and Evolution, vol. 271(1-2), 29-40.

Wójkiewicz B., Litkowiec M., Wachowiak W., 2016, Contrasting patterns of genetic variation in core and peripheral populations of highly outcrossing and wind pollinated forest tree species, AoB Plants, vol. 8 .

Vornam B., Kuchma O., Kuchma N., Arkhipov A., Finkeldey R., 2004, SSR markers as tools to reveal mutation events in Scots pine (Pinus sylvestris L.) from Chernobyl, European Journal of Forest Research, vol. 123(3), 245-248.

Zimin A., Stevens K. A., Crepeau M.W., Holtz-Morris A., Koriabine M., Marçais G., Neale D.B., 2014, Sequencing and assembly of the 22-Gb loblolly pine genome, Genetics, vol. 196(3), 875-89o.

(Web-1) EU Forest Law Enforcement, Governance and Trade Action Plan (FLEGT), http://eur-lex. europa.eu/legal-content/EN/TXT/?uri=CELEX:52003DCo251, dostęp 28.05.2018.

(Web-2) FAO. 2004, Preliminary review of biotechnology in forestry, including genetic modification. Forest Genetic Resources Working Paper FGR/59E. www.fao.org/docrep/oo8/ae574e/ae574eoo.htm, dostęp 28.05.2018. 


\title{
Antropogenic influence on the present genetic structure of forest tree populations
}

\begin{abstract}
Human activity has always had an impact on the species composition and genetic structure of species that make up the forest ecosystem. The results of DNA-based studies confirm the influence of current and past forest management on the current level of genetic variability of forest tree populations. Molecular analysis enables the study of gene flow between generations and reflects the history of post-glacial migration of species from southern refugia of Europe to Poland. Thanks to DNA markers, it is possible to precisely distinguish species hybrids, e.g. between Japanese and European larches. In timber trade market, the comparison of the DNA profiles of a stolen tree with a stump left in the forest provides strong evidence in judiciary pursuits concerning the illegal logging. Genetic transformation of the tree genome allows to obtain wood with altered lignin structure, higher increment and increased assimilation of $\mathrm{CO}_{2}$ in the leaves. Genetic modifications are also aimed at enhanced immunity of cultured tree species to fungal pathogens or insect pests and to plant protection products on fast-growing GMO trees.
\end{abstract}

\section{Keywords}

forest trees, DNA markers, genetic engineering, forest management 